\title{
Remodelling of the vertebral axis during metamorphic shrinkage in the pearlfish
}

\author{
E. Parmentier* $\dagger$, D. Lecchinił and P. Vandewalle $\dagger$ \\ $\dagger$ Laboratory of Functional and Evolutive Morphology, Bat. of Chemistry B6, University \\ of Liège, 4000 Liège, Belgium and \$Centre de Biologie et d'Ecologie Tropicale et \\ Méditerranéenne, Université de Perpignan, ESA CNRS 8046, 52, avenue de \\ Villeneuve, 66860 Perpignan Cedex, France
}

(Received 10 March 2003, Accepted 17 October 2003)

\begin{abstract}
Body shortening was observed in the pearlfish Carapus homei during metamorphosis. The tenuis larva at first possessed a suite of osseous vertebral bodies of similar length. The reduction in both the number and size of vertebrae followed increasing decalcification, degeneration of organic tissue and shortening. This involved a complete degradation and disappearance of the caudal tip vertebrae, and there was a reduction in the size of most of the remaining vertebrae. The further development of the vertebrae began with ossification of the neural and haemal arches before that of the vertebral body. This second part of the development followed a gradient: a gradual decreases towards the caudal tip in the size of the vertebrae and their completeness.

(C) 2004 The Fisheries Society of the British Isles
\end{abstract}

Key words: Carapus; development; metamorphosis; tenuis; vertebrae.

\section{INTRODUCTION}

In the animal kingdom, metamorphosis refers to an abrupt change in the form or structure of an organism during post-embryonic development, between the larval and juvenile phases (Youson, 1988). More than a change in form, the transformation also results in a change in physiology, behaviour and ecology (Fritzch, 1990; Balon, 1999). A drastic metamorphosis usually takes place before the change in habitat, e.g. the tadpole transforms into an adult before moving on land (Wassersug, 1996), the leptocephalous arguillid transforms in the sea before migrating into fresh water (Wang \& Tzeng, 2000), metamorphosed juvenile fishes leave the plankton to settle on the coral reef (Balon, 1999) and the larvae of flatfishes (Pleuronectiformes) metamorphose in the pelagic before moving to a benthic environment in estuaries (Marchand, 1992; Lagardère et al., 1999).

Although metamorphosis is known in various aquatic vertebrate groups, a description of development is rare and is only detailed in a few groups. A very

\footnotetext{
*Author to whom correspondence should be addressed. Tel.: +32 43665024; fax: +32 43663715; email: e.parmentier@ulg.ac.be
} 
conspicuous transformation is well known in lampreys (Youson, 1988), pleuronectiform flatfishes (Wagemans et al., 1998), elopomorphs (Pfeiler, 1999) and amphibians (Wassersug, 1989). Although the process is different, a common feature appears in various Elopomorpha (Pfeiler, 1999) and amphibians (Houdry \& Beaumont, 1995): a notable shortening of the body length during metamorphosis. The bonefish Albula sp. for example reduces its length by over 50\% (Pfeiler \& Luna, 1984). According to Markle \& Olney (1990), several Carapidae (Ophidiiformes) also undergo a drastic metamorphosis with a spectacular reduction of $50-60 \%$ in body length. The metamorphosis is so extreme that several carapid larvae were formerly considered as distinct species (Padoa, 1947). In the Carapidae, the behaviour of species of the Carapus and Encheliophis genera is quite unusual. They are able to penetrate and stay inside different invertebrate hosts such as holothuroids, asteroids and bivalves (Arnold, 1957; Trott, 1981; Parmentier et al., 2000). Carapus homei (Richardson) are usually found in the respiratory tree or in the body cavity of various species of sea cucumber including Bohadschia argus, Stichopus chloronotus, Stichopus variegates, Thelenota ananas and Actinopyga echinites (Smith, 1964; Smith \& Tyler, 1969; Trott, 1970, 1981; Markle \& Olney, 1990). These fishes, like other Carapus sp., are commensal: they leave their host in order to seek food, principally shrimp and small fishes (Trott \& Trott, 1972; Van Den Spiegel \& Jangoux, 1989; Vandewalle et al., 1998; Kloss \& Pfeiffer, 2000). Carapus species, however, are also cannibals and can eat other fishes inside their host (pers. obs.). Moreover, cannibalism on tenuis larvae (Carapus larvae) could be a major feeding pattern at some times of the year (Smith et al., 1981; Tyler et al., 1992). On the other hand, Encheliophis sp. are parasitic and feed principally on the respiratory trees and gonads of their host (Trott, 1970; Van Den Spiegel and Jangoux, 1989).

The life cycle of Carapus sp. is not well known. Spawning possibly takes place within the host since egg rafts were found in an aquarium containing a male and female Encheliophis gracilis (Bleeker) (parasite Carapidae) in an holothurian (Branch, 1969). The egg rafts should drift into the open sea where they hatch (Tyler et al., 1992). After hatching, the life cycle may be divided into four stages (Fig. 1): (1) the vexillifer larval stage is characterized by complex specialization of the dorsal fin with a highly modified first dorsal fin ray (vexillum); these larvae are planktonic (Emery, 1880; Arnold, 1956; Govoni et al., 1984); (2) the larva transforms into another type of larva, which is called 'tenuis', by a regression of the vexillum whilst the body lengthens considerably to $110-200 \mathrm{~mm}$ total length, $L_{\mathrm{T}}$, depending on the species (Padoa, 1947; Tyler et al., 1992; Parmentier et al., 2002a). At this stage, the Carapus sp. larvae leave the pelagic and may enter a benthic host for the first time (Arnold, 1956; Smith, 1964; Smith \& Tyler, 1969); (3) the juvenile stage is attained after a significant reduction of about a third of their length (Arnold, 1953; Smith et al., 1981; Markle \& Olney, 1990); (4) a further lengthening and thickening of the body leads to the adult form.

The transition from the tenuis larva to the juvenile stage is a 'true' metamorphosis. The present study investigated the changes of the axial skeleton from the tenuis larva to the juvenile stage in $C$. homei. 


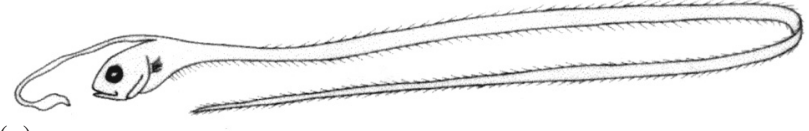

(a)

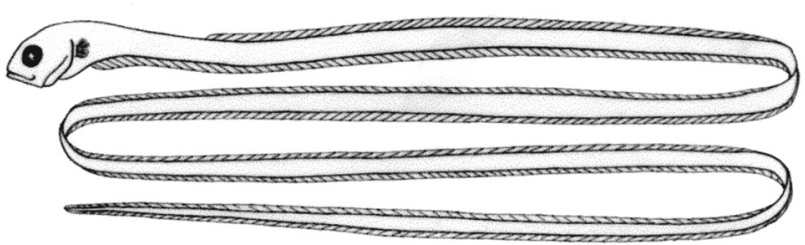

(c)

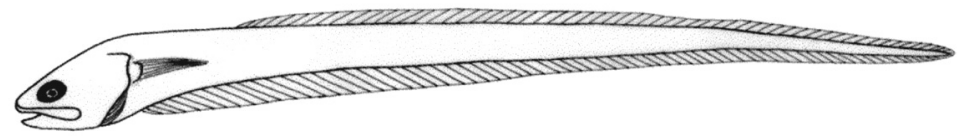

FIG. 1. Three different stages of Carapus homei. (a) Vexillifer $\left(110 \mathrm{~mm}\right.$, total length, $L_{\mathrm{T}}$ ), (b) tenuis $\left(185 \mathrm{~mm} L_{\mathrm{T}}\right)$ and (c) juvenile $\left(80 \mathrm{~mm} L_{\mathrm{T}}\right)$.

\section{MATERIALS AND METHODS}

Adult and juvenile specimens of $C$. homei were collected in Opunohu Bay, $\left(149^{\circ} 85^{\prime} \mathrm{E}\right.$; $17^{\circ} 5^{\prime}$ S) Moorea, French Polynesia. They were found, between July and August 2000, in the body cavity or in the respiratory trees of the holothurian Bohadschia argus. Carapus homei tenuis were caught when they arrived on the reef crest with a net similar to that used by Dufour et al. (1996). Six tenuis were placed with specimens of B. argus in different tanks running with sea water during 1 or 2 weeks. All experimental and caught specimens were anaesthetized in MS-222 and preserved in $70 \%$ ethanol. A total of 10 tenuis and five post-tenuis $C$. homei were used.

Different specimens of each developmental stage were stained either with alizarin red $S$ or with alcian blue according to the method of Taylor \& Van Dyke (1985). The coloured fish were dissected and examined with a Wild M10 binocular microscope coupled to a camera lucida.

Cross-sections were made in the middle and posterior part of tenuis larvae and juveniles. Slices of tissue were embedded in Paraplast. Histological sections were cut at $5 \mu \mathrm{m}$ and two kinds of staining were applied: Romer's colouring and Gallego's ferrous fuschine which emphasize the bone and cartilage.

\section{RESULTS}

In the tenuis larvae, the anterior vertebral bodies have a 'diabolo-like' form, are osseous and dorsally and ventrally flanked by thin cartilaginous neural and haemal arches (Fig. 2). Carapus homei tenuis larvae are between 149 and $183 \mathrm{~mm} L_{\mathrm{T}}(n=6)$ while the juveniles are much smaller, between 52 and $70 \mathrm{~mm} L_{\mathrm{T}}(n=3)$. The skeleton of the vertebral column of the tenuis larva is made of 177-198 osseous vertebral bodies of a similar shape, with a length of between 0.8 and $1.2 \mathrm{~mm}$ (Figs 2 and 3). Neural and haemal arches are present only in the form of thin cartilaginous rods except for the first three vertebrae where the neural arch is already ossified. These three vertebrae are the only ones to bear lateral epineural ribs.

Juveniles, on the other hand, have only 124-125 vertebrae. The anterior vertebrae are the most developed, with a vertebral body, a neural arch and ossified parapophyses (Fig. 2). Posterior to these vertebrae, the bones and 


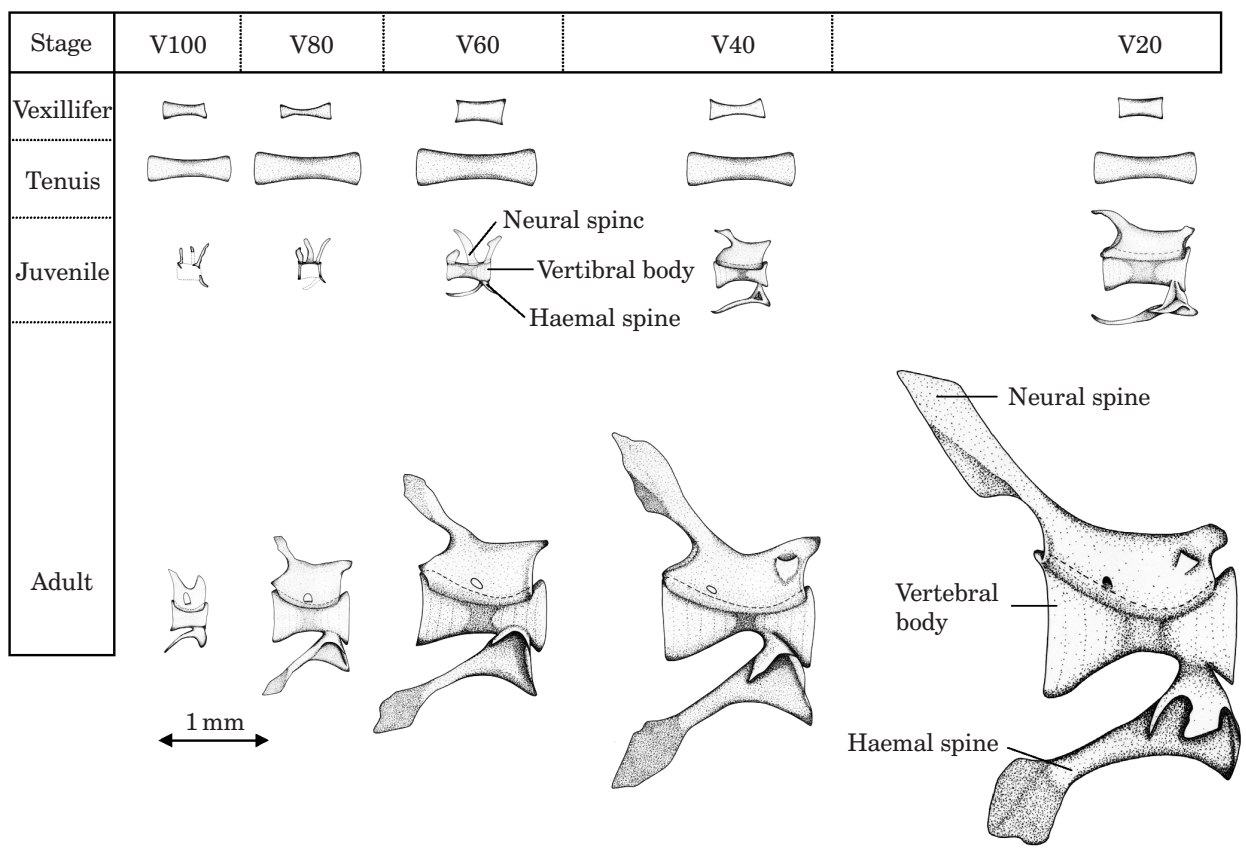

Fig. 2. Lateral view of the osseous vertebrae in Carapus homei at different developmental stages. V20-100, number of the vertebra counted from the posterior end of the skull.

their neural and haemal arches are gradually less complete and are reduced to 'mere outlines' at the caudal tip (Fig. 2). Unlike the tenuis larva caudal tip vertebrae, the caudal vertebral bodies of the juvenile are not completely ossified, but ossification is seen in the neural and haemal arches (Fig. 2). This difference in ossification is especially noteworthy because of the greater

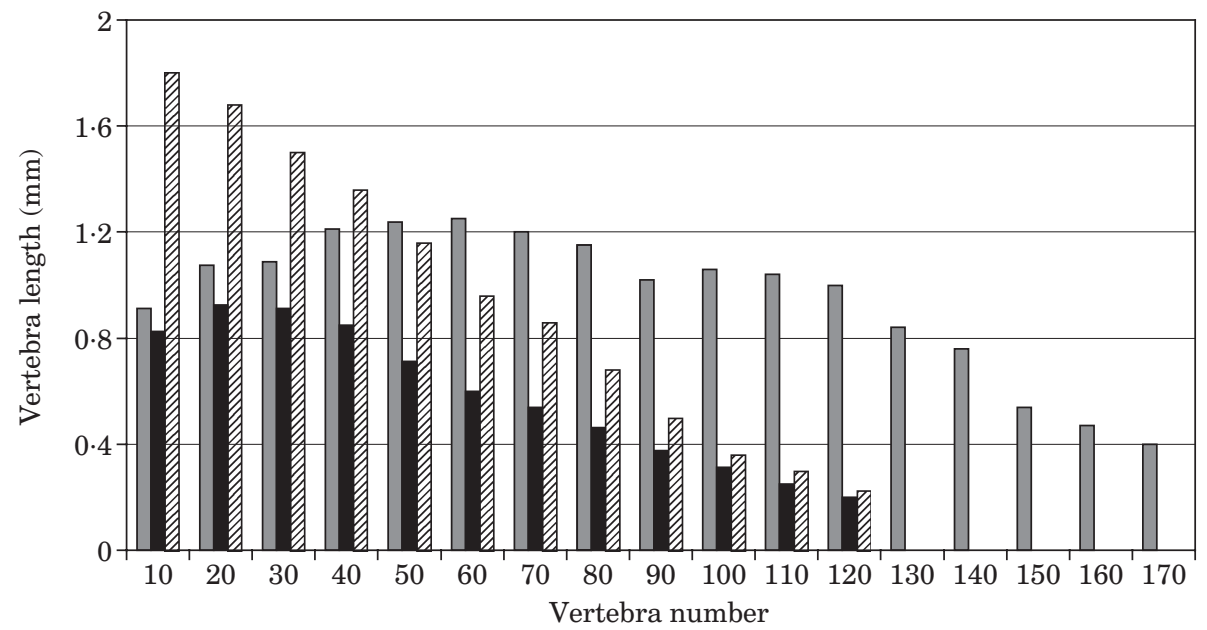

FIG. 3. Vertebra lengths of three Carapus homei at different developmental stages: tenuis larva ( $\square$ ) $\left(172 \mathrm{~mm} L_{\mathrm{T}}\right)$, juvenile $(\boldsymbol{\square})\left(75 \mathrm{~mm} L_{\mathrm{T}}\right)$, and adult $(\mathbb{Z})\left(132 \mathrm{~mm} L_{\mathrm{T}}\right)$. 
(a)

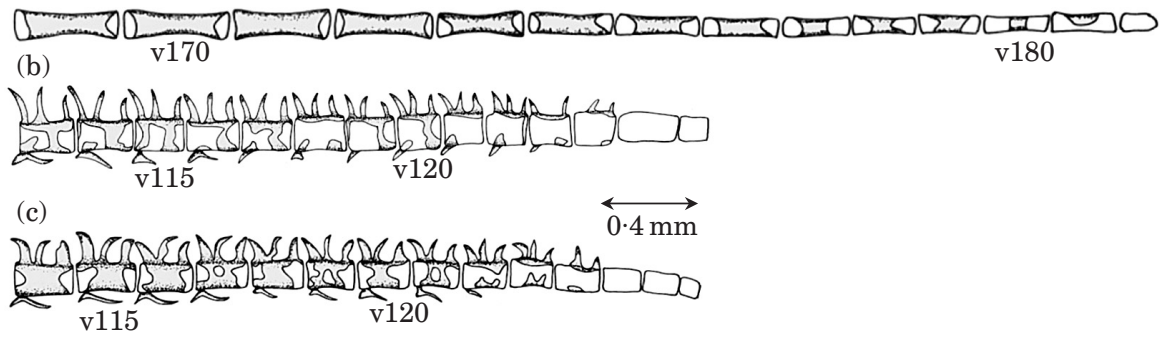

FIG. 4. Lateral view of the caudal tip in (a) the tenuis larva, (b) juvenile and (c) adult of Carapus homei. V115-180, vertebra number counted from the posterior end of the skull. Grey corresponds to the osseous parts of the vertebrae.

number of vertebrae in tenuis larvae (Fig. 4). Moreover, except for the first 10 vertebrae, all the juvenile's vertebrae are shorter than their counterparts in the tenuis larva and this difference becomes progressively more pronounced towards the tail. For example, the length of the 10th vertebral body in the juvenile is $88 \%$ of that in the tenuis larva; it is $49 \%$ for the 60 th vertebrae and $22 \%$ for the 100th (Fig. 3).

The vertebral column of the adult has the same number of vertebrae as the juvenile; the vertebrae are similar but more developed. The posterior vertebrae of the adult are also less complete than the anterior ones and are not totally ossified; their size is even smaller than those of the tenuis larvae (Figs 1, 2 and 4). In the vexillifer and tenuis larvae, juveniles and adults, each vertebra is related to one myoseptum. The length of the myomeres has hence decreased as has that of the vertebral centra.

In the tenuis larva, the ossified vertebrae completely surround the notochord (Fig. 5). These structures are enclosed in a sclerotome that extends around the nerve chord, the blood vessels and cartilaginous neural and haemal arches. In the developing vertebrae of the juvenile, the osseous tissue of the vertebral bodies appears thicker and bones also surround the cartilage of the neural and haemal arches, and the sclerotome is highly reduced (Fig. 5).

Observations of the tenuis larva at different stages of metamorphosis highlighted the following succession of events: the tenuis at first possessed a suite of vertebrae of similar length [Figs 2 and 6(a)]. The body shortening was linked to the loss of $c .60$ vertebrae and to the reduction in size of most of the remaining vertebrae. The further development of the posterior vertebrae began with the ossification of the neural and haemal arches [Figs 2 and 6(b)] before that of the vertebral body [Figs 2 and 6(c)]. This succession of events, however, was clear only in the caudal tip of the metamorphosing fish and a more complicated model was necessary for the whole axial skeleton.

\section{DISCUSSION}

In teleosts in general, the development and ossification of the neural and haemal arches precede those of the vertebral bodies (Potthoff et al., 1986, 1988; Powell \& Tucker, 1992; Koumoundouros et al., 1999). The vertebral mode of 


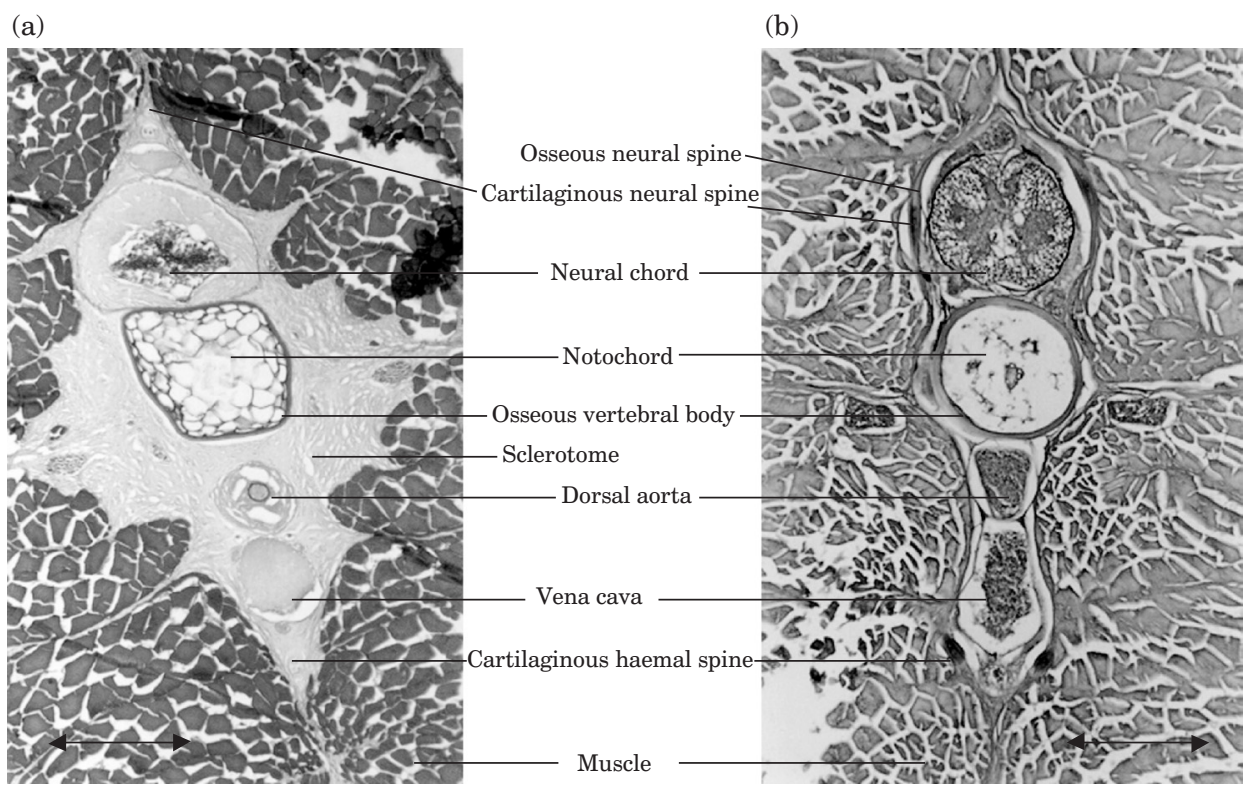

FIG. 5. Cross-section of the vertebral column in (a) a tenuis larva and (b) a juvenile of Carapus homei. Scale bar: $0.2 \mathrm{~mm}$.

development seems to be original in the $C$. homei tenuis larva where the formation of vertebral bodies precedes the ossification of the arches. In C. homei, the usual pattern of vertebral development described by Pothoff et al. (1988) is observed only in the caudal part after metamorphosis.

Generally speaking, the metamorphosis could be schematically explained in terms of gradients. The reduction of the number and size of vertebrae follows an increasing decalcification, histolysis and shortening gradient (Fig. 7). This results in a complete degeneration of organic tissue of the vertebrae of the caudal tip whereas the first 10 vertebrae are largely unaffected. The morphological modification of the axial skeleton from the juvenile to the adult (Fig. 2) could be explained by another gradient: a constructive gradient (Fig. 7), which decreases gradually towards the caudal tip and induces a vertebral axis with progressively shorter and less complete vertebrae. Additional data are needed, however, to determine the exact factors resulting in the gradient, to define the chronology of events and to quantify both gradients.

According to Youson (1988), metamorphosis is marked by an abrupt transformation from the larval phenotype. The metamorphosis involves two morphogenetic processes: 1) transformation of larval tissues and organs into those of the adult and 2) regression and eventual loss of larval structures.

Metamorphosis is accompanied by a shortening of the body length in numerous leptocephalus larvae (Pfeiler, 1999). In these the body axis consists of a gelatinous non-cellular matrix surrounded by a thin layer of muscle tissue (Pfeiler, 1999). The matrix provides structural support in the absence of a vertebral column, and later it provides the necessary energy and nutrients in the absence of exogenous nutrition during metamorphosis (Pfeiler, 1999). A 

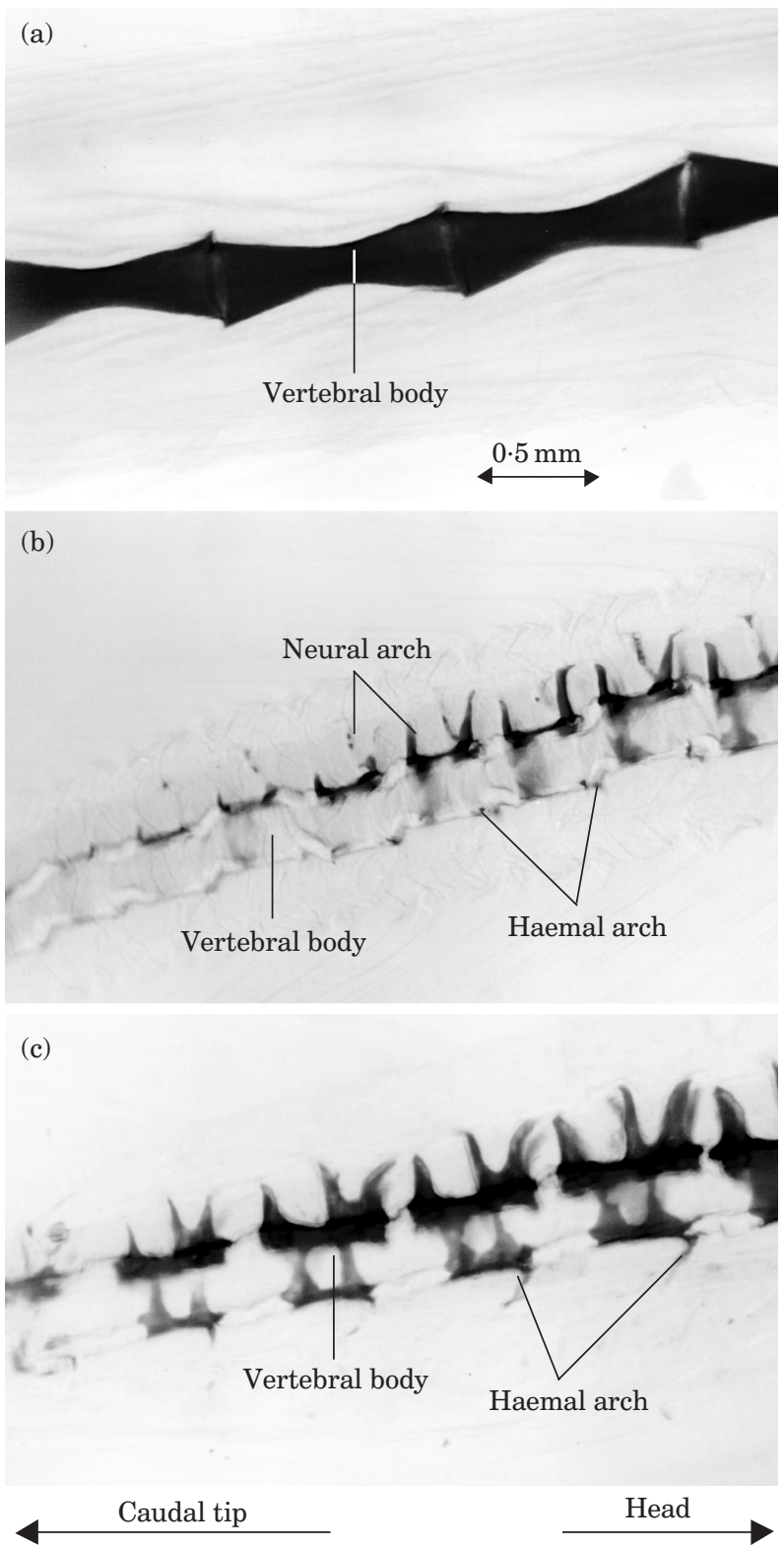

FIG. 6. Successive lateral views representing metamorphosis in the posterior part of the alizarin stained vertebrae. (a) Vertebral bodies in a tenuis larva caught at settlement. (b) Vertebrae of the caudal tip in a juvenile $\left(75 \mathrm{~mm} L_{\mathrm{T}}\right)$ after the body shortening. The re-ossification of decalcified and shortened vertebrae begins with the ossification of the neural and haemal arch. (c) The same as (b) in an older fish $\left(88 \mathrm{~mm} L_{\mathrm{T}}\right)$ The vertebral bodies are longer, the ossification of the arches is completed and the ossification of the vertebral body begins dorsally and ventrally.

strategy for the use of larval reserves also exists in anurans where the resorption of the tail could also provide the metabolites required for the elaboration of new tissues in the absence of exogenous food during metamorphosis (Houdry \& Beaumont, 1995). 
(a)

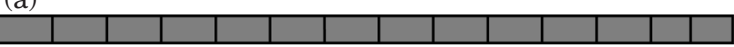

Decalcification and shortening gradient

(b)

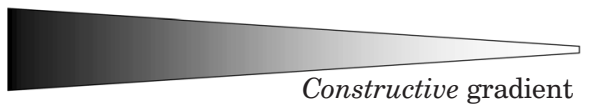

(c)

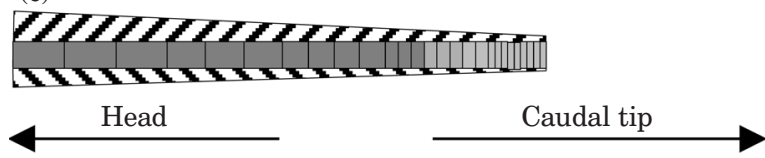

FIG. 7. Schematic representation of the metamorphosis of Carapus homei with two gradients. Modelling of the vertebral bodies in a tenuis larva (a) with a suite of ossified vertebral bodies. A metamorphosing fish (b) shows progressive decalcification and shortening of vertebrae, and the disappearance of the posterior vertebrae. A juvenile (c) shows the unequal sizes of vertebrae and neural and haemal arches (dark oblique lines). The transition from (a) to (b) could be induced by the 'decalcification, degeneration of organic tissue and shortening' gradient that is more important towards the tail. The transition from (b) to (c) could be induced by the 'constructive' gradient which is more important in the anterior part of the body.

In the tenuis larva, the reduction in size is not only the consequence of a reduction of the number of vertebra but also results in length diminution and osseous resorption of the remaining vertebrae. Possibly, the components of the degraded vertebrae and the breakdown of the sclerotome of the tenuis larva furnish the necessary metabolites for the formation of the anterior region in the juvenile, especially for the growth of the otoliths (Parmentier et al. 2002b) and in the development of the buccal apparatus (unpubl. data).

The unique feature of $C$. homei, however, lies in the ossification of all the vertebral bodies in the larval stage before metamorphosis. The vertebral column of leptocephalus larvae and the caudal tips of tadpoles are devoid of vertebrae or osseous supports, which appear only at the end of metamorphosis (Nishikawa \& Wassersug, 1988; Wassersug, 1989, 1996; Pfeiler, 1997; Tsukamoto \& Okiyama, 1997). This fundamental difference in the organization of the development could be related to their way of life. In order to enter its invertebrate host, the tenuis larva executes important body undulations (Arnold, 1956, pers. obs.) that would require a solid and flexible axial skeleton.

In non-symbiotic species, metamorphosis usually seems to occur before the settlement in a new environment (Marchand, 1992; Lagardère et al., 1999; Wang $\&$ Tzeng, 2000). On the other hand, in different parasitic species, the transition from a free living stage to a parasitic stage can also occur when the host is encountered. For example, diverse larvae of copepods and trematode cercariae develop fixing organs when they have found their host (Cassier et al., 1998; Bush et al., 2001). In C. homei, metamorphosis occurs also after the conquest of their new environment, the host. The caudal metamorphosis, however, does not 
seem to imply a morphological adaptation to the life inside the host but could rather be linked to the evolutionary history of the Carapidae. The tenuis stage, with an important body length shortening, appears to be present mainly in Carapidae species (Carapus, Encheliophis and Onuxodon), which have relationships with invertebrate hosts living on the reef crest. This shortening is far less important or non-existent in Carapidae species that live in the open sea (Nielsen et al., 1999). The commensal and parasitic species probably evolved from species living in open waters (Trott, 1970; Williams, 1984). As metamorphosis is the developmental strategy that has been selected to permit delay in development of definitive characteristics (Youson, 1988) and because the Carapidae larvae are pelagic, it is possible that, during their evolution, the body lengthening has been related to the longer lapse of time required to reach shallow waters and to find a host for the first time.

The metamorphosis leading from the tenuis larva to the juvenile in C. homei is unique among vertebrates. Its study could constitute an interesting biological model to better understand the phenomena of organic tissue degeneration and reorganization of the osseous structures and the influence of environmental factors on metamorphic processes. Observations on two other Carapini species, Carapus boraborensis (Kamp) and E. gracilis (pers. obs.) suggest that this peculiar metamorphosis could be typical at least of this Carapidae tribe.

We thank N. Decloux and G. Goffinet for helping in histological preparations. We are grateful to $\mathrm{M}$. Chardon and two anonymous referees for their constructive comments. C. Beans helped with the English. We thank also R. Rosenblatt (Scripps Institution of Oceanography, California), R.F. Feeney (Los Angeles Country Museum), J.T. Williams and S.L. Jewett (National Museum of Natural History of the Smithsonian Institution, Washington) and C. Nielsen (Zoologisk Museum Copenhagen) for providing vexillifer larvae for comparison with the tenuis. V. Dufour and his Aquafish Polynesia team provided different tenuis larvae. This work was supported by grant November 2.4560.96 from the Fonds National de la Recherche Scientifique of Belgium.

\section{References}

Arnold, D. C. (1953). Observation on Carapus acus (Brünnich) (Jugulares, Carapidae). Pubblicazioni della Stazione Zoologica di Napoli 24, 152-166.

Arnold, D. C. (1956). A systematic revision of the fishes of the teleost family Carapidae (Percomorphi, Blennioidea), with description of two new species. Bulletin of the British Museum (Natural History) 4, 247-307.

Arnold, D. C. (1957). Further studies on the behaviour of the fish Carapus acus (Brünnich). Pubblicazioni della Stazione Zoologica di Napoli 30, 263-268.

Balon, E. K. (1999). Alternative ways to become a juvenile or a definitive phenotype (and some persisting linguistic offenses). Environmental Biology of Fishes 56, 17-38.

Branch, J. B. (1969). Observation on the ecology and behavior of Guam pearlfishes (Carapidae). Thesis of Master of Science, University of Guam.

Bush, A. O., Fernandez, J. C., Esch, G. W. \& Seed, J. R. (2001). Parasitism. The Diversity and Ecology of Animal Parasites. Cambridge: Cambridge University Press.

Cassier, P., Brugerolle, G., Combes, C., Grain, J. \& Raibaut, A. (1998). Le parasitismeUn équilibre dynamique. Paris: Masson.

Dufour, V., Riclet, E. \& Lo-Yat, A. (1996). Colonization of reef fishes at Moorea Island, French Polynesia: Temporal and spatial variation of the larva flux. New Zealand Journal of Marine and Freshwater Research 47, 413-422. 
Emery, D. C. (1880). Le species del genere Fierasfere nel golfo di Napoli e regione limitrofe. Fauna und Flora Neapel 2, 1-76.

Fritzch, B. (1990). The evolution of metamorphosis in amphibians. Journal of Neurobiology 21, 1011-1021.

Govoni, J. J., Olney, J. E., Markle, D. F. \& Curtsinger, W. R. (1984). Observations on structure and evaluation of possible functions of the vexillum in larval Carapidae (Ophidiiformes). Bulletin of Marine Science 34, 60-70.

Houdry, J. \& Beaumont, A. (1995). La queue. In Traité de Zoologie, Tome IX (IA) (Popper, P. P., ed.), pp. 1067-1083. Paris: Masson.

Kloss, K. \& Pfeiffer, W. (2000). Zur biologie des «eingeweidefisches» C. acus (Brunnich, 1768) (Carapidae, Teleostei), mit hinweisen auf eine nich-parasitische ernähung. Revue Suisse de Zoologie 107, 335-349.

Koumoundouros, G., Divanach, P. \& Kentouri, M. (1999). Osteological development of the vertebral column and of the caudal complex in Dentex dentex. Journal of Fish Biology 54, 424-436. doi: 10.1006/jfbi.1998.0874.

Lagardère, F., Amara, R. \& Joassard, L. (1999). Vertical distribution and feeding activity of metamorphosing sole, Solea solea, before immigration to the bay of Vilaine nursery (nothern bay of Biscay, France). Environmental Biology of Fishes 56, 213-228.

Marchand, J. (1992). Métamorphose et passage pélagos/benthos chez la sole (Solea solea): synthèse des données acquises dans le site atelier de la Vilaine (1986-1990) et perspectives de recherche. Annales de l'Institut d'Océanographie 68, 141-150.

Markle, D. F. \& Olney, J. E. (1990). Systematics of the Pearlfish (Pisces: Carapidae). Bulletin of Marine Science 47, 269-410.

Nielsen, J. G., Cohen, D. M., Markle, D. F. \& Robins, C. R. (1999). FAO Species Catalogue, Vol. 18. Ophidiiform fishes of the world (order Ophidiiformes). An annotated and illustrated catalogue of pearlfishes, cusk-eels, brotulas and other ophidiiform fishes known to date. FAO Fisheries Synopsis 125, 1-178.

Nishikawa, K. \& Wassersug, R. (1988). Morphology of the caudal spinal cord in Rana (Ranidae) and Xenopus (Pipidae) tadpoles. Journal of Comparative Neurology 269, 193-202.

Padoa, E. (1947). Note di ittologia mediterranea. Nota V. Forme post-larvali e giovanili di Carapus (sin. Fierasfer). Pubblicazioni della Stazione Zoologica di Napoli 20, 111-121.

Parmentier, E., Castillo, G., Chardon, M. \& Vandewalle, P. (2000). Phylogenetic analysis of the pearlfish tribe Carapini (Pisces: Carapidae). Acta Zoologica 81, 293-306.

Parmentier, E., Lo-Yat, A. \& Vandewalle, P. (2002a). Identification of tenuis of four French Polynesia Carapini (Carapidae: Teleostei). Marine Biology 140, 633-638.

Parmentier, E., Lagardère, F. \& Vandewalle, P. (2002b). Relationships between inner ear and sagitta growth during ontogenesis of three Carapini species and consequences of life-history events on the otolith microstructure. Marine Biology 141, 491-501.

Pfeiler, E. (1997). Effects on $\mathrm{Ca}^{2+}$ on survival and development of metamorphosis bonefish (Albula sp.) leptocephali. Marine Biology 127, 571-578.

Pfeiler, E. (1999). Developmental physiology of elopomorph leptocephali. Comparative Biochemistry and Physiology (Part A) 123, 113-128.

Pfeiler, E. \& Luna, A. (1984). Changes in biochemical composition and energy utilization during metamorphosis of leptocephalous larvae of the bonefish (Albula). Environmental Biology of Fishes 10, 243-251.

Potthoff, T., Kelley, S. \& Javech, J. C. (1986). Cartilage and bone development in scombroid fishes. Fishery Bulletin U.S. 84, 647-678.

Potthoff, T., Kelley, S. \& Collins, L. A. (1988). Osteological of the red snapper, Lutjanus campechanus (Lutjanidae). Bulletin of Marine Science 43, 1-40.

Powell, A. B. \& Tucker, J. W. (1992). Egg and larval development of laboratory-reared nassau grouper, Epinephelus striatus (Pisces, serranidae). Bulletin of Marine Science 50, 171-185.

Smith, C. L. (1964). Some Pearlfishes from Guam, with notes on their ecology. Pacific Science 18, 34-40. 
Smith, C. L. \& Tyler, J. C. (1969). Observations on the commensal relationship of the western Atlantic pearlfish, Carapus bermudensis, and holothurians. Copeia 1969, 206-208.

Smith, C. L., Tyler, J. C. \& Feinberg, M. N. (1981). Population ecology and biology of the pearlfish (Carapus bermudensis) in the lagoon at Bimini, Bahamas. Bulletin of Marine Science 3, 876-902.

Taylor, W. R. \& Van Dyke, G. C. (1985). Revised procedure for staining and clearing small fishes and other vertebrates for bone and cartilage study. Cybium 2, 107-119.

Trott, L. B. (1970). Contribution of the biology of carapid fishes (Paracanthopterygian: Gadiformes). University of California Publication of Zoology 89, 1-41.

Trott, L. B. (1981). A general review of the pearlfishes (Pisces, Carapidae). Bulletin of Marine Science 31, 623-629.

Trott, L. B. \& Trott, E. B. (1972). Pearlfishes (Carapidae: Gadiforme) collected from Puerto Galera, Minobra, Philippines. Copeia 1972, 839-843.

Tsukamoto, Y. \& Okiyama, M. (1997). Metamorphosis of the Pacific Tarpon, Megalops cyprinoides (Elopiformes, Megalopidae) with remarks on development patterns in the Elopomorhpa. Bulletin of Marine Science 60, 23-36.

Tyler, J. C., Robins, C. R., Smith, C. L. \& Gilmore, R. G. (1992). Deepwater populations of the western Atlantic pearlfish Carapus bermudensis (Ophidiiformes: Carapidae). Bulletin of Marine Science 51, 218-223.

Van Den Spiegel, D. \& Jangoux, M. (1989). La symbiose entre poissons Carapidae et Holoturies autour de l'île de Laing (Mer de Bismarck, Papouasie Nouvelle Guinée). Indo- Malayasan Zoology 6, 223-228.

Vandewalle, P., Parmentier, E., Poulicek, M., Bussers, J. C. \& Chardon, M. (1998). Distinctive anatomical features of the branchial basket in four Carapidae species (Ophidiiformi, Paracanthopterygii). European Journal of Morphology 86, 153-164.

Wagemans, F., Focant, B. \& Vandewalle, P. (1998). Early development of the cephalic skeleton in turbot. Journal of Fish Biology 52, 166-204.

Wang, C. H. \& Tzeng, W. N. (2000). The timing of metamorphosis and growth rates of American and European eel leptocephali: a mechanism of larval segregative migration. Fisheries Research 46, 191-205.

Wassersug, R. J. (1989). Locomotion in Amphibian larvae (or 'Why aren't tadpoles built like fishes?'). American Zoologist 29, 65-84.

Wassersug, R. J. (1996). The biology of Xenopus tadpoles. In The Biology of Xenopus (Tinsley, R. C. \& Kobel, H. R, eds), pp. 195-211. Oxford: The Clarendon Press.

Williams, J. T. (1984). Synopsis and phylogenetic analysis of the pearlfish subfamily Carapinae (Pisces: Carapidae). Bulletin of Marine Science 34, 386-397.

Youson, J. H. (1988). First metamorphosis. In Fish Physiology, Vol. 11B (Hoar, W. S. \& Randall, D. J., eds), pp. 135-196. New York: Academic Press. 